\title{
CIÊNCIA, CIDADE E UTOPIA: XII Simpósio Nacional de Geografia Urbana (SIMPURB), Belo Horizonte, 16 a 19 de novembro de 2011
}

Eudes André Leopoldo de Souza*

\section{A Geografia Urbana demonstrou} fôlego e coragem em pensar as novas determinações do mundo moderno e o lugar da cidade e do urbano nessa tessitura crítica de contradições. Belo Horizonte, cujo seus primeiros traços arquitetônicos e urbanísticos vieram à luz como parte do projeto de modernidade em plena expansão universal na virada do século antecedente, foi o lugar onde discutimos, em contraponto, a crise da modernidade, o papel da ciência e a reformulação das utopias concretas em direção a constituição de um novo mundo possível.

Os diálogos foram traçados em torno da crítica e autocrítica da geografia urbana e das ciências parcelares, tendo em vista a identificação das nuances contemporâneas da produção do espaço urbano e possibilidades de superação das abstrações concretas que alienam e fazem parte, de maneira prática, da vida cotidiana das cidades. Sobre os alicerces, entre os edifícios, dentro da universidade, em vários momentos, habitamos uma das primeiras cidades brasileiras planejadas para repensarmos os sentidos de uma ciência preocupada com a emergência do urbano total. Talvez, por estarmos mergulhados no modo de produção capitalista, tenha se tratado de um habitar instantâneo, rarefeito, que não ultrapassou devidamente o limite da alienação espacial, uma reprodução do habitat, porém conduziu a uma nova experiência teórica e prática com os participantes do evento e com a capital mineira, seus elementos, conteúdos, ritmos e conflitos. Participar, mesmo que parcialmente, dos dramas da totalidade da cidade-sede e das experiências e problemáticas trazidas pelos habitantes de outras cidades brasileiras presentes no simpósio, nos permitiu tecer novas propostas, embalar um novo hino de liberdade, mesmo que ainda cambaleante, a partir dos traços do urbano possível inscritos naqueles lugares, associado com os de outros encontrados nos interstícios de nossos espaços vividos.

Nesse sentido, o encontro foi para além do cientificismo, tomou caráter de um momento explicitamente político, argumento que toma forma na ciranda das mesas e na sinfonia das discussões travadas nos grupos de trabalho. Na mesa de abertura, Sérgio Martins asseverou que "o pensamento não podia abrir as asas somente ao crepúsculo", era necessário um esforço mais contundente de ir para além da crítica ao mundo como fato consumado, da aparência imediata e transparência ilusória da realidade urbana; e além de conseguir captar a essência concreta e o âmago das contradições, era imprescindível trabalhar para a construção de utopias concretas.

\footnotetext{
* Mestrando em Geografia pela Universidade Estadual do Ceará (UECE). Email: eudesleopoldos@gmail.com
} 
Na mesma linha, João Antônio de Paula afirmou que "a utopia é o coroamento do processo de aprendizagem", entretanto, "enquanto no mundo antigo ciência e utopia estavam fundidas, no nosso mundo moderno elas estão separadas". Os desdobramentos desse divórcio estão inteiramente ligados à exaltação da razão e ao império da técnica, bem como aos interesses dos grandes capitalistas. Além disso, como "a utopia não é algo palatável ao crescente pensamento conservador e pós-moderno", ainda segundo as idéias de João Antônio de Paula, esse dualismo forçado entre as duas dimensões, ciência e utopia, tende a continuar; apesar de elas serem dimensões coextensivas, que dialeticamente se atraem e se repelem. A necessidade de pensar "o urbano como promessa emancipatória" e "a utopia como dimensão crucial na problemática da modernidade" foram as principais questões no início dos trabalhos.

Com giros dialéticos sobre os problemas urbanos, refletimos sobre os avatares do mundo da mercadoria; operações urbanas voltadas aos megaeventos esportivos; direito à cidade como utopia ou apenas como "o melhorar a cidade"; reprodução do capital imobiliário na urbanização capitalista; reestruturação urbana e metropolitana de caráter reformista e circunstancial; cultura e questões ambientais na cidade. Esse tratado de temas articulados, devidamente levantados e discutidos com maestria pelos professores e pesquisadores convidados e demais participantes, fecundou um rico espaço de debate, a partir da consciência crítica.

$\mathrm{Na}$ palestra de encerramento, Amélia Damiani lançou um manifesto e um convite: pensar a "produção do espaço urbano como grande maquinaria". Ela indica que este desafio requer trabalhar os seguintes níveis de análise: "negatividade absoluta do trabalho", "capitalização do urbano" e "devastação do tempo histórico". Ainda conforme argumenta a geógrafa, o movimento marxista de análise envolve a compreensão dos fetichismos, alienações e vivências que permeiam a vida cotidiana; todavia, é necessário "explodir os dogmatismos marxistas" e "não temer transpor as fronteiras das ciências parcelares", rumo a uma "dialética do espaço". Lançando mão de sua concepção de mundo materialista e leituras de intelectuais como Karl Marx, Henri Lefebvre, Guy Debord, Amélia Damiani acredita que a prática urbana subsumida explode no espaço frio e puro, no grau zero, ao mesmo tempo em que, nesse espaço abstrato podem surgir os relevos e sítios psicogeográficos, vivências que sinalizam as possibilidades do salto mortale na transição possível do reino da necessidade para o reino da liberdade. Sem dúvida nenhuma, esse ponto de vista não significa um messianismo nem uma protelação do projeto revolucionário posto sempre no futuro em nome do reformismo e do perspectivismo, que abraçam os novos pactos sociais em todas as esferas da vida. Pelo contrário, é a apresentação do possível em marcha, a esperança cifrada.

Frente às novas fronteiras do conhecimento abertas pela complexidade do espaço e complicadas por uma pletora de fenômenos que não se situam na velha relação causa-efeito e às controvérsias nascidas do ventre das idéias e práticas pósmodernas que olham as microtexturas e inobservam a totalidade de relações; a força da Geografia urbana radical mostrou a potência reveladora de uma nova Geografia crítica menos escrava do marxismo ortodoxo do que aberta ao movimento do real, determinações essenciais e movimentos 
libertários que afloram por toda parte. Ilumina-se que o avanço da tecnologia, turbulência e aceleração do tempo atual não podem ser impeditivos da construção de novas teorias pela aparente fugacidade do real e muito menos das utopias de transformação revolucionária da reprodução das relações sociais de produção. Assim, vale assinalar um trecho da película $O$ Paciente Inglês (1996), indicado por Odette Seabra em um dos momentos dos grupos de trabalho: "somos os verdadeiros países, não as fronteiras nos mapas, com nomes de homens poderosos", a nossa luta então é por "uma terra sem mapas", onde cada um seja visto em sua integridade e partícipe de uma comunidade de igualdade de condições, o urbano emergindo então como materialidade desse período.
Os geógrafos são fundamentais nesse processo através da crítica profunda a esse estado de coisas e a participação no desenvolvimento da mudança radical do mundo. As doses homeopáticas de criação crescente de imperativos consumistas e os paliativos psicodélicos de ilusões ideológicas e espetaculares devem ser desmascarados, trazidos à tona e confrontados com as superfícies transparentes e enganadoras.

Enfim, no XII SIMPURB, nos corredores e dinâmicas de Belo Horizonte, experimentamos algo novo, caminhamos ao encontro de novas posturas intelectuais, pensamos na superação da oposição teoriaprática e da cisão ciência-utopia, compartilhamos conhecimentos, reforçamos a nossa crença nas tendências de insurreição do homem. 